\title{
Insurance Guaranty Schemes in a Contingent Claims Setting
}

\author{
Hato Schmeiser · Joël Wagner
}

Published online: 30 September 2011

(C) Springer-Verlag 2011

\begin{abstract}
The introduction of an insurance guaranty scheme can have significant influence on the pricing and capital structures in a competitive market. This contribution summarizes the major findings of a working paper written by Schmeiser and Wagner (Working Papers on Risk Management and Insurance (IVW-HSG), No. 80, 2010). The effect on competitive equity-premium combinations is studied while considering a framework with policyholders and equity holders where guaranty fund charges are volume-based, as levied in existing schemes. Several settings with regard to the origin of the fund contributions are assessed and the immediate effects on the incentives of the policyholders and equity holders are analyzed through a one-period contingent claim approach. One result is that introducing a guaranty scheme in a market with competitive conditions entails a shift of equity capital towards minimum solvency requirements. Hence adverse incentives may arise with regard to the overall security level of the industry.
\end{abstract}

Zusammenfassung Die Einführung eines Insolvenzsicherungsfonds in einem kompetitiven Marktumfeld kann einen erheblichen Einfluss auf die Preisgestaltung und die Kapitalstruktur eines Versicherers ausüben. Der vorliegende Beitrag stellt eine Zusammenfassung der zentralen Erkenntnisse aus einem Arbeitspapier von Schmeiser und Wagner (Working Papers on Risk Management and Insurance (IVW-HSG), No. 80, 2010) dar. Die Modellanalyse erfolgt dabei aus der Perspektive der Versicherungsnehmer und der Aktionäre und untersucht, welche Effekte sich durch ein volumenbasiertes Insolvenzsicherungsfondssystem auf Eigenkapital-PrämienKombinationen in einem optionspreistheoretischen Kontext ergeben. In der Analyse

This contribution summarizes the major findings of a working paper written by Schmeiser and Wagner (2010) that was presented at the annual meeting of "Deutscher Verein für Versicherungswissenschaft e.V.” in Berlin, March 2011.

H. Schmeiser · J. Wagner $(\bowtie)$

Institute of Insurance Economics, University of St. Gallen, Kirchlistrasse 2, 9010 St. Gallen, Switzerland

e-mail: joel.wagner@unisg.ch 
der Implikationen für die zentralen Stakeholdergruppen zeigt sich als ein Kernergebnis, dass die Einführung eines Insolvenzsicherungsfonds Anreize zum Herabsetzen des Eigenkapitals in Richtung Mindestsolvenzanforderungen schafft. Dadurch können sich durch die in Rede stehenden Regulierung durch Insolvenzsicherungsfonds tatsächlich kontraproduktive Effekte hinsichtlich der Sicherheit der Versicherungsindustrie ergeben.

\section{Introduction}

In many countries, insurance guaranty schemes are set up to cope with part of the obligations of insolvent insurers. Over the past decades, guaranty funds have been introduced when a country's insurance sector has assisted, as a cooperative effort with the regulator, in the liquidation of one (or more) defaulting companies. One example is the German life insurer Mannheimer Lebensversicherung (344,000 life insurance contracts) which had been in a situation of financial distress and hence was absorbed in 2003 by a funded rescue company named Protektor. Today, Protektor acts as an insurance guaranty fund and a general rescue company for the German life insurance industry. ${ }^{1}$ Recent turbulence in the financial markets stressed the need for a review of the regulations in-force. The latter include solvency measurement (e.g., European Union Solvency II), and the reconsideration, or installation where non-existent, of customer guaranty systems - and this also for the banking and the insurance area. While the review of banking deposit insurance systems in the European Union has led to higher caps in the last year and months with homogenization by the end of 2011 (see, e.g., Council 2008), the insurance sector has no comparable comprehensive system. Definitely, even if adequate supervision can reduce the default probability of an insurer, making taxpayers, and the entire society, pay in the case of insolvencies is difficult to legitimate. A recent example, even though the core insurance business may not have been the main trigger, is the bailout of insurance giant AIG in 2008 where it is still unclear whether taxpayers ever will be fully repaid.

As part of the European Union's response to the economic and financial crisis, ${ }^{2}$ the European Commission announced that it would review the adequacy of existing guaranty schemes in the insurance sector. The initiative (see European Commission 2010a), based on work undertaken since 2001, is planned to lead to the adoption of a White Paper by 2010, setting out a European solution on insurance guaranty schemes. Whereas in the United States each state has two guaranty associations, one for life and the other for property-liability insurance, both associations being incorporated in national organizations, the landscape of insurance guaranty schemes in Europe is heterogeneous. An extensive analysis of existing guaranty schemes in the European Union in 2007 (Oxera 2007, p. 7) accounted for 13 countries out of the 27 Member

\footnotetext{
${ }^{1}$ Other considerable examples in Europe include the bankruptcy of the Danish insurer Plus Forsikring in 2002, Britain's Independent Insurance in 2001, and France's Europavie in 1997. Further case descriptions and figures regarding the number of insurance failures, including the U.S.A., can be found, for example, in Oxera (2007, Sect. 4.5f).
}

${ }^{2}$ See the European Union's online portal. http://ec.europa.eu/financial-crisis. 
States, having introduced relevant schemes supporting either the life or non-life insurance sectors, or part of these. ${ }^{3}$ The guaranty scheme system of the various countries is very similar, but its extent is non-uniform. From a (cross-border) European perspective, many questions arise when facing the challenge of unification, or the fund volume needed (see also European Commission 2010b). The lack of harmonized insurance guaranty scheme arrangements in the European Union hinders effective and equal consumer protection. In light of the lessons drawn from the recent crisis, the development of harmonized guaranty schemes could contribute to remedy the existing deficiencies, while in particular not impeding the operation of the internal insurance market by distorting cross-border competition. It thus seems important to us to point out that, by 2010 , about $26 \%$ of all life insurance policies in the European Union and $56 \%$ of all non-life insurance policies were unprotected (European Commission 2010b).

One important aspect is that most of the existing insurance guaranty fund schemes charge premiums that are not directly linked to insurer risks. ${ }^{4}$ From this, one can expect adverse incentives for insurers and cross-subsidization between market players. This has been largely discussed in literature: Early analysis by Cummins (1988) affirms that well designed insurance guaranty funds should demand risk-based premium payments, in order to avoid adverse incentives. With respect to regulation implications, pricing aspects are further discussed, for example, by Cummins and Lamm-Tennant (1994) and Cummins and Sommer (1996). The work by Duan and Yu (2005) extends the Cummins (1988) model to a multi-period setting, calculating insurance guaranty premiums in the presence of risk-based capital regulations. The issue of a system with ex-post charges not being able to be organized in a truly riskbased way due to the fact that the insolvent insurance company, which may have been the riskiest one, is typically not charged at all, is extensively addressed, for example, by Han et al. (1997, p. 1119). The merits of pre-funding and post-financing are discussed for example by Yasui (2001, p. 13): ex-ante levies have the advantage of enabling relatively quick handling of insolvency cases since funds for policyholder compensation are always available. This is especially important in dealing with the bankruptcy of a larger insurer, for which a considerable amount of funds needs to be mobilized within a short period of time. Furthermore, the existence of a sufficient amount of funds for policyholder protection ensures the visibility of a safety net and thus contributes to the maintenance of public confidence in the industry. However, the ready-to-use funds may induce moral hazard behavior of consumers, companies and supervisors and, moreover, given its visibility, the lack of sufficient funds may adversely affect public confidence. Also, while pre-funding allows better predictability for member companies, in regard to (foreseen) future financial burdens, post-financing has the advantage of requiring virtually no administration costs (such as fund management costs) until an insolvency case comes out: member companies

\footnotetext{
${ }^{3}$ In addition, other protection mechanisms besides the introduction of an insurance guaranty fund are discussed in Oxera (2007, Sect. 3). In this context, the reasons for the installation of an insurance guaranty fund are given and the desired market outcomes, as well as the potential wrong incentives and transaction costs, are derived (see Oxera 2007, Sects. 3.1-3.5).

${ }^{4}$ An exception from this rule is the German life insurance guaranty fund scheme, where charges depend on company ranking according to their financial capacity, defined as equity relative to solvency margin.
} 
can retain funds until these funds become of immediate necessity. Rymaszewski et al. (2010) examined under which conditions a self-supporting insurance guaranty fund can be beneficial for policyholders. In their framework, the concept of utility-based premiums is introduced and possible diversification benefits are measured through a change in utility for risk-averse policyholder collectives.

Another set of contributions analyzes the existing guaranty scheme systems, almost exclusively with respect to the U.S. system. Recent work by Bernier and Mahfoudhi (2010) discusses guaranty schemes from Canada and the U.S. with respect to the incentives due to ex-post levies. Feldhaus and Kazenski (1998) discuss modelbased alternatives, in particular bankruptcy prediction models and class rating, for U.S. insurance guaranty schemes, with the perspective on a risk-based assessment rather than the actual "flat-rate" feature where the assessment provides no penalties to insurers who choose to engage in more risky operations. The affecting factors identified include the premium growth and concentration, level of loss reserves, retention and financial leverage. Most closely to our approach, Sommer (1996) examines the impact of an insurer's level of insolvency risk on the prices that the insurer obtains for its products in the property-liability insurance market. With regard to guaranty funds, Sommer (1996) points out that in a system with flat-rate premium-based charges, not only do guaranty funds not receive a higher premium for a higher-risk firm, but the funds actually receive lower premiums from a risky firm than from a safe firm, since the risky firm takes in less in premium revenue. This yields the wrong outcome of reverse risk-based guaranty fund premiums. This element also appears in our later discussion of stakeholder positions. Looking into effects on company organization, the work of Ligon and Thistle (2007) shows that, in the presence of guaranty funds that levy non-risk-adjusted premium-based charges, the riskiness of the policyholder loss distribution affects the company organizational structure: heterogeneity in consumer riskiness creates incentives for a separate insurance firm for each consumer type.

Arising from the current effort in the European Union, the scope of this paper is to analyze the effects of introducing insurance guaranty scheme systems in a market with established equity-premiums. An overview of existing guaranty funds in the European Union can be found in Oxera (2007), the latter is updated and extended in Schmeiser and Wagner (2010). We focus on the introduction of an insurance guaranty scheme, in a setting of established competitive premiums with respect to equity. It is assumed that the stakes of policyholders and equity holders are at equilibrium with respect to risk-adequacy. This equilibrium is disturbed with the considered introduction of a guaranty scheme. As is mostly done in practice, we assume the guaranty scheme to be funded through contributions calculated as a fraction of the company's premium income and processed ex-ante. The guaranty fund ensures complete policyholder coverage, if necessary considering complementary ex-post charges to insurers or borrowing money from the state, for example. The case with limited liability of the fund, i.e., expressed as a percentage or as an absolute cap on claims, is discussed. Analysis is carried out using a one-period contingent claim approach. Under the assumption that the insurer is solely charged by the fund, without charging the policyholders back, the policyholder protection level and position is increased to the detriment of the insurer, who is charged. A second case analyzes the situation 
where policyholders are charged directly by the fund. Whenever the contribution is not "fair", adverse incentives arise, e.g., through a reduction of the company security level. Finally, a setting where policyholders are charged the fair premium corresponding to their additional protection received, is considered. In this case, the policyholder premiums and contributions are partially allocated to the insurer and the fund respectively. Here, the allocation is crucial and the premium rate charged sets the safety level of the insurance companies.

This summary is structured as follows: In Sect. 2, we introduce a model framework where we formally describe the different stakeholder positions in a contingent claim approach, in settings without and with a guaranty fund. In Sect. 3, we give a synoptical overview of implications and incentives for the different stakeholders after the introduction of an insurance guaranty scheme. We present our conclusions in Sect. 4.

\section{Analysis of Stakeholder Positions in a Contingent Claim Model}

This section introduces a one-period contingent claim model framework, for an insurance company based on a model first proposed by Doherty and Garven (1986). ${ }^{5}$ We consider the neo-classical framework of finance, i.e., we assume in particular complete and arbitrage-free markets. The model framework used allows for a riskadequate positioning of the involved stakeholders. We adapt it here for three stakeholders, namely policyholders and equity holders of the insurance company, as well as, after its introduction, the insurance guaranty fund. The used claims structure explicitly takes insolvency risk into consideration: the value of the default put option introduced below is a measure for the insurer's safety level (see also, e.g., Phillips et al. 1998 and Gatzert and Schmeiser 2008).

In a first step (see Sect. 2.1), initial and fair positions of policyholders and equity holders are exposed in a setting without guaranty fund. All positions are assumed to be at equilibrium from a risk-adequate point of view. This means that "fair" returns on the initial contributions are derived from the policyholder premiums or the equity holder capital respectively (see, e.g., Sherris 2006 or D'Arcy and Dyer 1997). In a second step, an insurance guaranty fund is introduced (see Sect. 2.2). Depending on the guaranty scheme funding mechanism, the risk-adequate equilibrium is disturbed. The immediate effects on the positions of the various stakeholders are summarized in Sect. 3.

\subsection{Stakeholder Positions Without Guaranty Fund}

Let $E_{0}$ denote the insurance company's initial equity paid-in by investors and let $P_{0}$ be the up-front premium paid by the policyholders. Premiums are considered net of costs. Hence, the opening cash flow is given by the sum

$$
A_{0}=E_{0}+P_{0},
$$

\footnotetext{
${ }^{5}$ In order to focus on the core aspects regarding guaranty schemes, we will omit tax effects in our discussion. See also Footnote 7.
} 
and can be invested in the capital market. At time $t=0$, the nominal value of the insurer's liabilities, or of the policyholder claims, is $L_{0}$.

\subsubsection{Policyholder Position at Maturity}

At the end of the period, at time $t=1$, the position of the insured parties grants the policyholders the coverage of their claims $L_{1}$ if the company is solvent, i.e., if the available assets $A_{1}$ at time $t=1$ exceed the liabilities $L_{1}$. In the event of insurer insolvency at time $t=1$, when liabilities exceed the assets, i.e., $L_{1}>A_{1}$, policyholders receive only the market value of the insurer assets. Assets $A_{1}$ and liabilities $L_{1}$ are assumed to follow stochastic processes. Hence, the indemnity payment $P_{1}$ to policyholders at maturity is given by

$$
P_{1}=\min \left(L_{1}, A_{1}\right)=L_{1}-\left(L_{1}-A_{1}\right)^{+},
$$

where $(\cdot)^{+}=\max (\cdot, 0)$. The present value of the policyholder position, $\Pi_{0}^{P}$, can be written as

$$
\Pi_{0}^{P}=\mathrm{PV}\left[P_{1}\right]=\mathrm{PV}\left[L_{1}\right]-\mathrm{PV}\left[\left(L_{1}-A_{1}\right)^{+}\right]=\Pi_{0}^{L}-\Pi_{0}^{\mathrm{DPO}},
$$

where PV stands for the valuation operator and the present value of the default put option (DPO) is given by $\Pi_{0}^{\mathrm{DPO}}=\mathrm{PV}\left[\left(L_{1}-A_{1}\right)^{+}\right]$.

In (3), the present value of the claim costs is equal to the nominal value of the issued liabilities $\Pi_{0}^{L}=\operatorname{PV}\left[L_{1}\right]=L_{0}$. The second term reflects the insolvency cost, widely discussed, for example, by Cummins (1988), Butsic (1994) and by Sommer (1996). When using this present value calculation, the risk is incorporated in the insurance rate, since it reduces the default-free premium $\Pi_{0}^{L}$ to $\Pi_{0}^{P}$. This implies that insurers with higher (lower) present value of the insolvency risk will charge lower (higher) premiums.

\subsubsection{Equity Holder Position at Maturity}

The equity holder stake at maturity, $E_{1}$, is residually determined by the difference between the value of the assets $A_{1}$ and the aggregated liabilities $L_{1}$, i.e.,

$$
E_{1}=A_{1}-P_{1}=\left(A_{1}-L_{1}\right)^{+} \text {. }
$$

Consequently, the present value of the equity holder position, $\Pi_{0}^{E}$, is given by

$$
\Pi_{0}^{E}=\mathrm{PV}\left[E_{1}\right]=\mathrm{PV}\left[\left(A_{1}-L_{1}\right)^{+}\right] \text {. }
$$

\subsubsection{Fairness Condition}

The value of the policyholders position $\Pi_{0}^{P}$ can be called a "fair" or competitive premium, if it equals the initial contribution by the policyholders, i.e., if

$$
P_{0}=\Pi_{0}^{P}
$$


holds. This situation leads to a net present value of zero for the insured parties, the latter receiving a risk-adequate return with respect to their initial contribution. To be called "fair" or arbitrage-free, the value of the equity holder payoff $\Pi_{0}^{E}$ must equal their initial contribution $E_{0}$, i.e.,

$$
E_{0}=\Pi_{0}^{E}
$$

Since the sum of the equity holder and policyholder positions equals the available assets, i.e., $E_{t}+P_{t}=A_{t}$, for times $t=0,1$, (6) is equivalent to (7), i.e., we have

$$
P_{0}=\Pi_{0}^{P} \Leftrightarrow E_{0}=\Pi_{0}^{E} .
$$

Hence, an infinite number of initial equity-premium combinations $E_{0}-P_{0}$, with different values for the default put option $\Pi_{0}^{\mathrm{DPO}}$ are possible. These lead to net present values of zero for both equity holders and policyholders. From an economical point of view, this means that insurance companies choose a specific "security" level, i.e., solvency-level, by defining the equity endowment $E_{0}$. However, minimum capital requirements in regulatory solvency frameworks define a lower bound for the solvencylevel, i.e., the insurer's equity $E_{0}$.

\subsection{Three Settings for Funding a Guaranty Scheme}

The introduction of an insurance guaranty fund with compulsory participation by all insurance companies is considered under three different assumptions, with respect to the source and magnitude of fund contributions levied from policyholders and equity holders. Below, we introduce the different settings in detail and give a summary of the various stakeholder situations-policyholder, equity holder and guaranty fund positions-in Table 1 (see Sect. 3).

In all settings, let $C_{0}^{*}$ denote the ex-ante mandatory contribution to the guaranty fund. In exchange for the contribution $C_{0}^{*}$, the guaranty fund assures all policyholders a fraction $\beta$ of their claims $L_{1}, 0 \leq \beta \leq 1$, up to a maximum amount $\Gamma, \Gamma \geq 0$. In the case where $\beta=1$ with $\Gamma \geq \beta L_{1}=L_{1}$, the scheme guarantees complete protection $(100 \%)$ of their claims without cap (no bound on maximum amount), if their insurer is insolvent at maturity. The case $\beta=0$ corresponds to a situation without any guarantee. 6

\subsubsection{Setting A: Funding of Guaranty Scheme by Insurance Companies}

In a first setting, we assume that the guaranty scheme is funded ex-ante and entirely by insurance companies. Furthermore, the levy is assumed not to be charged back by the insurers to their policyholders. Hence policyholder payments are not affected by the introduction of the guaranty fund and they pay the same risk premium to the

\footnotetext{
6 The derivation of the stakeholder positions in Sect. $2.2 \mathrm{ff}$ considers the general case $0 \leq \beta \leq 1, \Gamma \geq 0$ for setting A. In order to simplify the formulation and keep the discussion to the core aspects, the presentation of the other settings is limited to the case where the guaranty fund assures $100 \%$ of the policyholder claims with no cap, i.e., we set $\beta=100 \%$ and $\Gamma \geq L_{1}$.
} 
insurance company. This setting is realistic when justified higher premiums cannot be implemented in the market. In practice, this is the case in a market where policyholders are not aware of the existing default risk of insurers and the limited protection of their claims.

The contribution $C_{0}^{*}$ charged to insurance companies is calculated as a fraction $\alpha, 0 \leq \alpha<1$, of the premium volume $P_{0}^{*}$. In fact, this is in line with most existing insurance guaranty schemes, see, e.g., Schmeiser and Wagner (2010, Sect. 2). Note that other allocation methods accounting for the net reserves, mathematical provisions or number of policies could be represented similarly by adapting this model framework. ${ }^{7}$

If $E_{0}^{*}$ and $P_{0}^{*}$ denote the initial contributions at time $t=0$ of equity holders and policyholders respectively, the available assets $A_{0}^{*}$ are given by $A_{0}^{*}=E_{0}^{*}+P_{0}^{*}-C_{0}^{*}$. If we assume that the initial investments $E_{0}^{*}=E_{0}$ and $P_{0}^{*}=P_{0}$ are identical in both situations, with and without guaranty scheme, we obtain

$$
A_{0}^{*}=A_{0}-C_{0}^{*} .
$$

We assume that the assets in $A_{0}^{*}$ are invested under the same conditions as $A_{0}$.

Similarly to the situation without guaranty fund (see (2)), the indemnity payment at time $t=1$ from the insurance company with available assets $A_{1}^{*}$ to the policyholders with claims $L_{1}$ is given by

$$
P_{1}^{*, A}=\min \left(L_{1}, A_{1}^{*}\right)=L_{1}-\left(L_{1}-A_{1}^{*}\right)^{+} .
$$

In the presence of the above described guaranty scheme, let $P_{1}^{*, F}$ denote the policyholder indemnity payment from the fund at time $t=1$. Since the fund guarantees a fraction $\beta$ of the policyholder claims up to a maximum $\Gamma$, the policyholder aggregated position $P_{1}^{*}=P_{1}^{*, A}+P_{1}^{*, F}$ is given by $\max \left(P_{1}^{*, A}, \min \left(\beta L_{1}, \Gamma\right)\right)$, and hence

$$
P_{1}^{*, F}=\left(\max \left(P_{1}^{*, A}, \min \left(\beta L_{1}, \Gamma\right)\right)-P_{1}^{*, A}\right)^{+}=\left(\min \left(\beta L_{1}, \Gamma\right)-P_{1}^{*, A}\right)^{+} .
$$

An illustration of the described setting and of the cash flows is given in Fig. 1.

\subsubsection{Setting B: Guaranty Scheme Funded Directly by Policyholders}

Secondly, we consider a setting where the guaranty fund charges policyholders directly, or through the insurers who charge the contributions integrally back to the policyholders. In this situation, the insurance company, and hence its equity holders, are not affected. This system is in place in most countries for the special motor insurance schemes where the premium paid by policyholders for car liability insurance incorporates the fund levy. Some countries, e.g., Spain, have implemented such a system explicitly in the funding rules of the guaranty scheme.

\footnotetext{
7 In this model framework we do not account for taxation, transaction costs and other frictional costs. Since, for example, the ex-ante levies paid by the insurer to the guaranty fund would be deductible from tax payments, the reduction of the latter have repercussions on the profit, the prices and the equity capital. Price regulation and the impact of corporate taxes have been studied in details by Doherty and Garven (1986), as well as by Gatzert and Schmeiser (2008).
} 


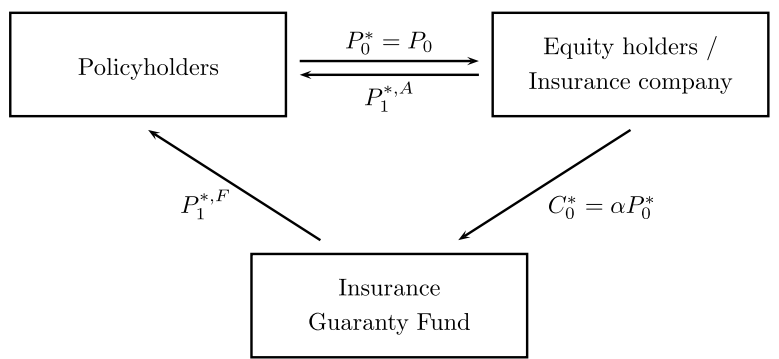

Fig. 1 Cash flows in setting A. Illustration of the cash flows with an insurance guaranty fund at times $t=0$ and $t=1$ in setting A. Contributions $C_{0}^{*}$ to the fund at time $t=0$ originate from the insurance company and are not charged back to policyholders, whose initial premium payment $P_{0}^{*}=P_{0}$ is not affected. The indemnity payment to policyholders at time $t=1$ comes partly from the insurance company $\left(P_{1}^{*, A}\right)$ and the fund $\left(P_{1}^{*, F}\right)$

The ex-ante contribution $C_{0}^{*}$ charged to policyholders is calculated as a fraction $\alpha$, $0 \leq \alpha<1$, of the premium volume $P_{0}^{*}$. The guaranty fund is assumed to ensure full policyholder claim protection (see Footnote $6, \beta=100 \%$ and $\Gamma \geq L_{1}$ ).

If $E_{0}^{*}$ and $P_{0}^{*}$ are the initial contributions of equity holders and policyholders at time $t=0$, the available assets in the insurance company are given by $A_{0}^{*}=E_{0}^{*}+$ $P_{0}^{*}-C_{0}^{*}$. If we assume that $E_{0}^{*}=E_{0}$ and $P_{0}^{*}=P_{0}+C_{0}^{*}$, this implies that

$$
A_{0}^{*}=E_{0}+P_{0}=A_{0} .
$$

Comparing the insurer's asset situation with that in setting A (see (9)), we note that the policyholder contribution $C_{0}^{*}$ to the fund has no influence on the insurer's available capital.

Since $A_{0}^{*}=A_{0}$, we have $A_{1}^{*}=A_{1}$, and the indemnity payment $P_{1}^{*, A}$ from the insurance company to the policyholders at time $t=1$ is derived from (10),

$$
P_{1}^{*, A}=P_{1}=L_{1}-\left(L_{1}-A_{1}\right)^{+},
$$

and equals the insurer's payment to the policyholders in the absence of a guaranty scheme (see (2)). Furthermore, the indemnity payment $P_{1}^{*, F}$ from the guaranty scheme (offering full protection) yields the value of the insurer default put option, i.e.,

$$
P_{1}^{*, F}=\left(L_{1}-A_{1}\right)^{+},
$$

such that $P_{1}^{*}=P_{1}^{*, A}+P_{1}^{*, F}=L_{1}$.

The cash flows in this setting are illustrated in Fig. 2.

\subsubsection{Setting C: Guaranty Scheme Funded by Policy- and Equity Holders}

Finally, we consider a guaranty scheme funded ex-ante by contributions from the insurance companies (setting A), but where policyholders pay a (fair) premium to their insurer corresponding to the cumulated protection received from the insurance 


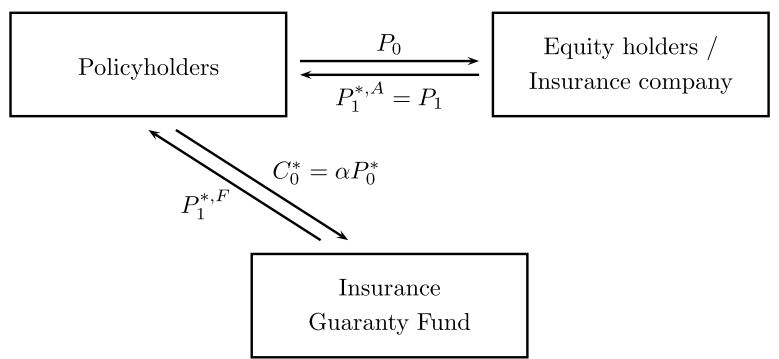

Fig. 2 Cash flows in setting B. Illustration of the cash flows with an insurance guaranty fund at times $t=0$ and $t=1$ in setting B. Contributions $C_{0}^{*}$ to the fund at time $t=0$ originate from the policyholders whose initial premium payment $P_{0}$ to the insurer is not affected. The total position $P_{0}^{*}$ corresponds to $P_{0}$ complemented by the contribution $C_{0}^{*}$ to the fund. The indemnity payment to policyholders at time $t=1$ comes partly from the insurance company $\left(P_{1}^{*, A}=P_{1}\right)$ and the fund $\left(P_{1}^{*, F}\right)$

company and the guaranty fund. In other words, though the guaranty fund ensures full protection of the policyholder liabilities, the latter pay the default risk-free premium $P_{0}^{*}=\Pi_{0}^{L}$ to the insurance company.

The insurer is charged a contribution $C_{0}^{*}$ by the guaranty fund, calculated as a fraction $\alpha, 0 \leq \alpha<1$, of the premium volume $P_{0}^{*}$. In this case, the default riskfree premium paid to the insurer is partially transferred to the guaranty fund. In this setting, it is assumed that the fund fully ensures policyholder liabilities.

If $E_{0}^{*}$ and $P_{0}^{*}$ are the initial contributions of equity holders and policyholders at time $t=0$, the available assets in the insurance company are given by $A_{0}^{*}=E_{0}^{*}+$ $P_{0}^{*}-C_{0}^{*}$. We assume again that the initial investments $E_{0}^{*}=E_{0}$ and we have $P_{0}^{*}=$ $\Pi_{0}^{L}$, hence

$$
\begin{aligned}
A_{0}^{*} & =E_{0}+\Pi_{0}^{L}-C_{0}^{*}=E_{0}+P_{0}+\Pi_{0}^{\mathrm{DPO}}-C_{0}^{*} \\
& =A_{0}+\Pi_{0}^{\mathrm{DPO}}-C_{0}^{*},
\end{aligned}
$$

where $\Pi_{0}^{\mathrm{DPO}}=\operatorname{PV}\left[\left(L_{1}-A_{1}\right)^{+}\right]$stands for the present value of the default put option first introduced in (3). We assume that $A_{0}^{*}$ is invested in the same assets as $A_{0}$.

At time $t=1$, the indemnity payment from the insurance company with available assets $A_{1}^{*}$, to the policyholders with claims $L_{1}$ is given by $P_{1}^{*, A}$ formally defined in (10) (see setting A):

$$
P_{1}^{*, A}=L_{1}-\left(L_{1}-A_{1}^{*}\right)^{+}
$$

Similarly, the formal description of the guaranteed fund's payment $P_{1}^{*, F}$ to the policyholders is given by (11), which in the case with $\beta=100 \%$ and $\Gamma \geq L_{1}$ is written as:

$$
P_{1}^{*, F}=\left(L_{1}-P_{1}^{*, A}\right)^{+}=\left(L_{1}-A_{1}^{*}\right)^{+} .
$$

The cash flows in this setting are illustrated in Fig. 3. 


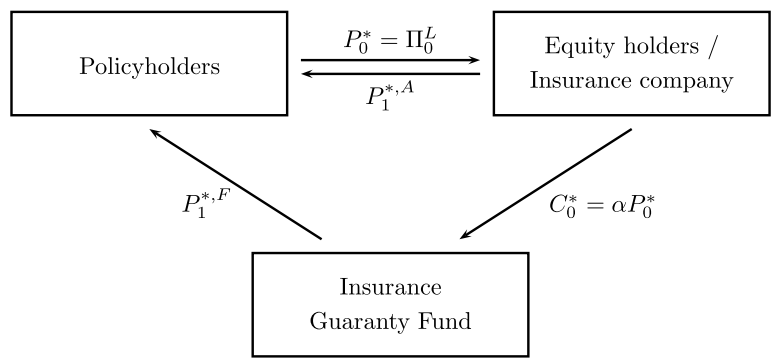

Fig. 3 Cash flows in setting C. Illustration of the cash flows with an insurance guaranty fund at times $t=0$ and $t=1$ in setting C. Policyholders are assumed to have full protection of their claims through the insurance company and the fund. They are charged the default risk-free premium $\left(P_{0}^{*}=\Pi_{0}^{L}\right)$. Contributions $C_{0}^{*}$ to the fund at time $t=0$ originate from the insurance company. The indemnity payment to policyholders at time $t=1$ comes partly from the insurance company $\left(P_{1}^{*, A}\right)$ and the fund $\left(P_{1}^{*, F}\right)$.

\section{Overview of Settings and Implications on Stakeholder Positions}

In Table 1 we present a synoptical overview of the different settings introduced. The settings considered and the main results on the stakeholder positions obtained are recapitulated. The formal derivation of the effects and the discussion from the point of view of the various stakeholders in each setting, as well as numerical illustrations can be found in the working paper by Schmeiser and Wagner (2010).

\section{Conclusion}

An international landscape analysis of existing insurance guaranty funds is the basis for the study of the effects of the introduction of guaranty scheme systems in markets with established equity-premiums at equilibrium. Fund contributions are in most cases calculated as a percentage of the company premium volume and risk-weighting in the contributions of the different market players is mostly inexistent.

The focus of the theoretical analysis lies in the study of the disturbance of the established market equilibrium, with respect to policyholder premium payments and insurer equity endowments, when a pre-funded guaranty scheme is introduced. The stakeholder positions are analyzed in a one-period contingent claims model framework allowing for a risk-adequate positioning. The claims structure used explicitly takes insolvency risk, i.e., the insurer's safety level, into consideration. The introduction of the guaranty fund is considered under three different assumptions with respect to the source and magnitude of fund contributions levied from policyholders and equity holders.

Main results include that in all cases adverse incentives with regard to the insurer safety level arise whenever the guaranty fund contribution is not risk-adequate and stakeholders are not charged fairly. The incentives include for equity holders the lowering of the equity capital endowment down to the limits required by solvency regulations, or for policyholders the change towards a company charging lower premiums, i.e., with a lower safety level. Finally we conclude that, under the assumption 
Table 1 Recapitulation of implications and incentives for the different stakeholders after the introduction of an insurance guaranty scheme

\begin{tabular}{|c|c|c|c|}
\hline Setting & Policyholder position & Equity holder position & Guaranty fund situation \\
\hline A & $\begin{array}{l}\text { - Same premium payment } \\
P_{0}^{*}=P_{0} \text {. } \\
\text { - Realistic when policy- } \\
\text { holders are unaware of } \\
\text { change of default risk } \\
\text { through the introduction } \\
\text { of a guaranty fund. } \\
\text { - NPV equals value of in- } \\
\text { surer DPO } \Pi_{0}^{\mathrm{DPO}} \text {. }\end{array}$ & $\begin{array}{l}\text { - Contribution } C_{0}^{*}=\alpha P_{0} \\
\text { to the fund (no charge } \\
\text { back to policyholders). } \\
\text { - NPV is negative. } \\
\text { - Incentive to lower equity } \\
E_{0}^{*}=E_{0}^{\text {fair }} \leq E_{0} \text { to re- } \\
\text { store fair situation. }\end{array}$ & $\begin{array}{l}\text { - NPV equals } \Pi_{0}^{*, D P O}- \\
C_{0}^{*} \text {. } \\
\text { - Self-financing only if } \\
\text { funds equal insurer's } \\
\text { value of DPO. }\end{array}$ \\
\hline B & $\begin{array}{l}\text { - Premium } P_{0}^{*}=P_{0}+C_{0}^{*}, \\
C_{0}^{*}=\alpha P_{0}^{*} \text { as fund contri- } \\
\text { bution. } \\
\text { - } \mathrm{NPV} \text { equals to }\left(\Pi_{0}^{\mathrm{DPO}}-\right. \\
\alpha \Pi_{0}^{L} /(1-\alpha) . \\
\text { - } \text { If } \alpha>\alpha^{\text {fair }}= \\
\Pi_{0}^{\mathrm{DPO}} / \Pi_{0}^{L}, \quad \text { incentive } \\
\text { to change to insurer with } \\
\text { lower premiums (equity) } \\
\text { to restore fair situation. }\end{array}$ & $\begin{array}{l}\text { - No contribution to the } \\
\text { fund, } E_{0}^{*}=E_{0} \text {. } \\
\text { - NPV is unaffected. } \\
\text { - In practice insurer would } \\
\text { collect policyholder con- } \\
\text { tribution and transfer to } \\
\text { fund. }\end{array}$ & $\begin{array}{l}\text { - } \mathrm{NPV} \text { equals } \Pi_{0}^{\mathrm{DPO}}- \\
C_{0}^{*} \text {. } \\
\text { - Self-financing only } \\
\text { if funds equal in- } \\
\text { surer's value of DPO } \\
\left(\alpha \geq \alpha^{\text {fair }}\right) \text {. }\end{array}$ \\
\hline $\mathrm{C}$ & $\begin{array}{l}\text { - } \text { Premium } P_{0}^{*}=\Pi_{0}^{L}= \\
P_{0}+\Pi_{0}^{\mathrm{DPO}} \text {. } \\
\text { - NPV equals to zero. } \\
\text { - Policyholders pay default } \\
\text { risk-free premium and get } \\
\text { full protection through the } \\
\text { combination of insurer } \\
\text { and guaranty scheme. }\end{array}$ & $\begin{array}{l}\text { - Contribution } C_{0}^{*}=\alpha P_{0} \\
\text { to the fund, } E_{0}^{*}=E_{0} \text {. } \\
\text { - } \mathrm{NPV} \text { zero } \\
C_{0}^{*}=\Pi_{0}^{\mathrm{DPO}} \text {. } \\
\text { - If situation is unfair, } \\
\text { incentive to adapt eq- } \\
\text { uity capital (and hence } \\
\Pi_{0}^{\mathrm{DPO}} \text { ) to restore fair sit- } \\
\text { uation. Parameter } \alpha \text { fixes } \\
\text { target solvency level. }\end{array}$ & $\begin{array}{l}\text { - } \mathrm{NPV} \text { equals } \Pi_{0}^{*, D P O}- \\
C_{0}^{*} \text { (see setting A). } \\
\text { - If situation for in- } \\
\text { surers is fair, fund is } \\
\text { self-financing (adequate } \\
\text { value of assets in system } \\
\text { equity holders-guaranty } \\
\text { scheme). }\end{array}$ \\
\hline
\end{tabular}

Contributions $C_{0}^{*}$ are ex-ante, calculated as a fraction of the premium volume $\alpha P_{0}$, and the guaranty fund is supposed to offer full protection to policyholders. Notations refer to those introduced above. In particular: $\mathrm{NPV}=$ Net Present Value, DPO = Default Put Option

of volume-based fund contributions, a unique fair situation for all stakeholders is defined when setting the level of the fund contribution. In the same way, the overall's industry safety level is fixed. Since the impact of the introduction of a guaranty scheme can be huge, the magnitude of volume-based levies should be analyzed carefully, not only with regard to the needed funds but also with regard to the incentives and implications generated.

\section{References}

Bernier, G., Mahfoudhi, R.M.: On the economics of postassessments in insurance guaranty funds: a stakeholders perspective. J. Risk Insur. 77(4), 857-892 (2010) 
Butsic, R.P.: Solvency measurement for property-liability risk-based capital applications. J. Risk Insur. 61(4), 656-690 (1994)

Cummins, J.D.: Risk-based premiums for insurance guaranty funds. J. Finance 43(4), 823-839 (1988)

Cummins, J.D., Lamm-Tennant, J.: Capital structure and the cost of equity capital in the property-liability insurance industry. Insur. Math. Econ. 15(2-3), 187-201 (1994)

Cummins, J.D., Sommer, D.W.: Capital and risk in property-liability insurance markets. J. Bank. Finance 20(6), 1069-1092 (1996)

D'Arcy, S., Dyer, M.: Ratemaking: a financial economics approach. In: Proceedings of the Casualty Actuarial Society, vol. 84, pp. 301-390 (1997)

Doherty, N.A., Garven, J.R.: Price regulation in property-liability insurance: a contingent-claims approach. J. Finance 41(5), 1031-1050 (1986)

Duan, J.-C., Yu, M.-T.: Fair insurance guaranty premia in the presence of risk-based capital regulations, stochastic interest rate and catastrophe risk. J. Bank. Finance 29(10), 2435-2454 (2005)

ECOFIN Council: Implementing a European Response to the Financial Crisis, October (2008)

European Commission: White paper on insurance guarantee schemes (2010a). http://ec.europa.eu/ internal_market/insurance/guarantee_en.htm

European Commission: Insurance Guarantee Schemes (IGS)—frequently asked questions, MEMO/10/320, 12 July (2010b)

Feldhaus, W.R., Kazenski, P.M.: Risk-based guaranty fund assessments. J. Insur. Regul. 17(1), 42-63 (1998)

Gatzert, N., Schmeiser, H.: The influence of corporate taxes on pricing and capital structure in propertyliability insurance. Insur. Math. Econ. 42(1), 50-58 (2008)

Han, L.-M., Lai, G.C., Witt, R.C.: A financial-economic evaluation of insurance guaranty fund system: an agency cost perspective. J. Bank. Finance 21(8), 1107-1129 (1997)

Ligon, J.A., Thistle, P.D.: The organizational structure of insurance companies: the role of heterogeneous risks and guaranty funds. J. Risk Insur. 74(4), 851-861 (2007)

Oxera: Insurance guarantee schemes in the EU: comparative analysis of existing schemes, analysis of problems and evaluation of options (2007). http://ec.europa.eu/internal_market/insurance/docs/ guarantee_schemes_en.pdf

Phillips, R.D., Cummins, J.D., Allen, F.: Financial pricing of insurance in the multiple-line insurance company. J. Risk Insur. 65(4), 597-636 (1998)

Rymaszewski, P., Schmeiser, H., Wagner, J.: Under what conditions is an insurance guaranty fund beneficial for policyholders? J. Risk Insur. (forthcoming)

Schmeiser, H., Wagner, J.: The impact of introducing insurance guaranty schemes on pricing and capital structures. Working Papers on Risk Management and Insurance (IVW-HSG), No. 80 (2010)

Sherris, M.: Solvency, capital allocation, and fair rate of return in insurance. J. Risk Insur. 73(1), 71-96 (2006)

Sommer, D.W.: The impact of firm risk on property-liability insurance prices. J. Risk Insur. 63(3), 501 (1996)

Yasui, T.: Policyholder Protection Funds: Rationale and Structure, Part 1, 2. Organisation for Economic Co-operation and Development (OECD) (2001). http://www.oecd.org/daf/ insurance-pensions/ 